\title{
Discussions on Talent Training of E-commerce Major
}

\author{
Huili Wang \\ Wuchang Institute of Technology, Wuhan Hubei, 430223, China
}

Key words: E-Commerce, Professional talent, Training.

\begin{abstract}
Due to the sustainable development of modern science and technology and constant deepening of the integration of world economy, Chinese e-commerce industry has realized unprecedented rapid development and is gradually applied to and integrated into various levels of social and economic development in all directions, thus causing great demands of e-commerce enterprises for professional e-commerce talents. However, the total employment rate of graduates majoring in e-commerce in Chinese institutions of higher learning is not high and the supply and demand of e-commerce talents are disconnected. Therefore, it is very necessary to analyze e-commerce talent training mechanism of Chinese colleges and universities and improve professional e-commerce talent training system more appropriate for actual demands of China.
\end{abstract}

\section{Introduction}

Due to the great development of modern information technology industry including network technology in recent years, the quantity and quality of professional e-commerce talents required by the society have been improved continuously. However, the employment situation of graduates majoring in e-commerce in Chinese institutions of higher learning is not optimistic in recent years. The phenomenon of difficulty in employment is quite obvious. Great demands of employers for professional e-commerce talents and difficulty of graduates majoring in e-commerce in institutions of higher learning in employment have great conflicts. This requires us to deeply analyze the reason for this situation and improve the existing professional talent training system of e-commerce in institutions of higher learning in China on this basis.

\section{Analysis on status of professional talent demands of e-commerce in China}

In recent years, the quantity demanded of e-commerce and internet talents is always high and shows a trend of constant increase according to the total quantity of talent demand in each industry. According to statistics of Chinese E-commerce Research Center, Chinese employers have strong demands for professional e-commerce talents. At least 43\% e-commerce enterprises conduct personnel recruitment activities of a certain scale. Statistical data of Taobao show that e-commerce talent gap on Taobao platform is up to one million and it is predicted that the quantity demanded of e-commerce talents will reach 4.5 million in the next three years. The great gap of talent demands causes the lack of high-quality talents in the current e-commerce industry, great difficulty of enterprise recruitment and extremely fierce talent competition among e-commerce enterprises, thus causing great mobility of professional e-commerce talents. Some enterprises even seize talents with high price, thus causing comprehensive loss of high-quality e-commerce talents in enterprises of the same industry. Meanwhile, over five hundred institutions of higher learning in China have set up e-commerce major and hundreds of thousands of graduates majoring in e-commerce go to the employment market each year. However, as talent training mechanism of institutions of higher learning in China and enterprise practice are seriously disconnected, many college graduates cannot adapt to actual talent demands of 
e-commerce enterprises, thus causing difficulty of both graduates and employers respectively in employment and recruitment. For institutions of higher learning, how to transform the inherent talent training mode of e-commerce major and make it more adapted to actual requirements of rapid updating and constant innovation of e-commerce industry knowledge is a central issue that universities must attach great importance to in e-commerce talent training.

\section{Main problems existing in current professional e-commerce talent training in China}

First, unclear positioning of e-commerce major. Interdisciplinary feature and industry development of e-commerce major determine that it belongs to developing major. It is in the stage of constant exploration in both practice and theory. Compared to other traditional majors, it is very difficult to master the positioning of e-commerce major. Universal positioning of professional training easily occurs, thus causing inadequacy of graduates in professional knowledge and skill structure. As graduates in institutions of higher learning have limited learning energy and have to learn relevant knowledge and skills but only scratch the surface, they get lost in the major. Second, low professional teaching quality of some universities. Currently, curriculum system of e-commerce major in colleges and universities is very wide and comprehensive, thus requiring teachers to have a high professional quality and wide scope of knowledge. However, many colleges and universities attach inadequate importance to professional teaching, thus causing the phenomenon of perfunctoriness in professional teaching. Therefore, college students cannot master professional knowledge and skills of e-commerce comprehensively and accurately. There is a great gap with realistic work situation and the professional ability of graduates is lacking. Third, lagging construction of professional teaching staff in some colleges and universities. After great development of e-commerce major, the construction of professional teaching staff will play a decisive role. As e-commerce major is still in the development stage in China, there are no teachers majoring in e-commerce at the beginning of professional construction. Teachers are mainly transferred from other majors. Some teachers are originally those of computer or electrical and electronic majors or economic and marketing majors. Some are students staying in school. Since the expansion of enrollment of Chinese colleges and universities in 1999, some colleges and universities have selected many undergraduates to enrich teacher resources due to the lack of teachers in each major. These teachers have the problem of inadequate professional ability. Fourth, inadequacy of practical education of e-commerce major. The improvement of practical ability seems very important for graduates of e-commerce major in institutions of higher learning. Practical education is indispensable in classroom teaching process. However, there are more theoretical courses of e-commerce major in institutions of higher learning. The period of practical courses is very limited and most of them stay within intramural operation and fail to integrate into the specific work of employers in the society. For example, theoretical study of entrepreneurial practice course generally has a period of four weeks. Therefore, many courses are only learnt with formalism and students cannot experience it comprehensively and deeply. Meanwhile, facilities in intramural training room of e-commerce in some colleges and universities are lagging and can hardly adapt to actual operation mode of e-commerce in the current rapid development. Therefore, lagging practical teaching greatly influences e-commerce talent training in Chinese colleges and universities.

\section{Path selection for training of high-quality professional e-commerce talents}

\section{Specify positioning of professional e-commerce talent training}

It is required to attach great importance to the positioning of training objectives of professional e-commerce talents and enhance the close connection between e-commerce talent training and relevant industries of e-commerce. Currently, e-commerce talent training in China has entered the stage of market segmentation characterized by paying attention to industry application and providing 
customized services of this industry. E-commerce activities of each industry not only have common features, but also have their particularity, thus causing the difference of e-commerce application in different industries, such as e-commerce + tourism industry, e-commerce + agricultural product industry and e-commerce + medical industry. Obviously, undifferentiated talent training commonly implemented in current institutions of higher learning can hardly meet the demand of career planning of graduates majoring in e-commerce and industry development. Therefore, it is urgent to refine the positioning of e-commerce talent training continuously. Institutions of higher learning should positively determine the positioning of e-commerce talent training based on features of their industry-oriented education. For example, some medical vocational college has set up medical e-commerce major. Its training objective is to combine e-commerce and medical and health industry closely. Its talent training positioning is to possess high-quality and highly skilled talents required by various posts such as online pharmaceutical marketing, construction of pharmaceutical e-commerce platform, pharmaceutical industry customer relation management and drug bidding and purchasing. It can realize comprehensive integration of profession and industry.

\section{Improve e-commerce talent education and teaching system in institutions of higher learning}

E-commerce industry belongs to high-growth emerging industry. Its industry development is much faster than the absorption and conclusion of theoretical knowledge. E-commerce major courses in institutions of higher learning should manifest the frontier development trend of the industry accurately and timely. This requires timely updating and improvement of contents of professional teaching. The most important issue of all institutions of higher learning since their establishment up to constant development and expansion is to improve the quality of classroom teaching because teaching quality is always the core link of higher education. Teaching ability directly concerns the school-running quality of a college and is the decisive factor among various factors determining its talent training quality. Without teacher groups with good professional quality, the improvement of school-running quality of e-commerce major will be water without a source. Therefore, institutions of higher learning should attach great importance to the construction of e-commerce talent education and teaching system, guide teachers to organize and carry out education and teaching activities and purchase advanced teaching instrument to allow college students to make use of these advanced facilities for learning. Specific to teaching equipment of e-commerce major, the above mainly refers to multi-media hardware equipment, relevant software equipment and the latest version of e-commerce operating software etc.

\section{Build teacher group adapted to e-commerce talent training}

Considering that current enterprises urgently need high-quality practical talents of e-commerce major, institutions of higher learning should be committed to training high-quality practical talents required by e-commerce enterprises. This requires professional e-commerce teachers with practical ability. To improve the practical teaching ability of professional e-commerce teachers in institutions of higher learning, there are mainly two ways for teacher training: first, introduce e-commerce insiders with good practical skills from e-commerce enterprises or other colleges. Currently, e-commerce has a good development momentum in China. Senior talents in enterprises generally are unwilling to teach in a college. Therefore, most institutions of higher learning introduce teaching talents from other colleges and universities. It is also required to cultivate the practical ability of professional e-commerce teachers, dispatch e-commerce teachers to e-commerce enterprises for learning in a planned and purposeful way and try to invite senior management of enterprises to give a lesson to teachers and students with spare time on this basis so as to improve the quality and ability of professional teachers.

\section{Attach more importance to practical teaching of e-commerce major}

First, improve the proportion of period of practical course of e-commerce major. E-commerce major is strongly practical. Therefore, it is required to increase the proportion of practical teaching of 
specialized courses with strong application as much as possible, such as e-commerce safety, e-commerce website planning, network marketing and other backbone courses. Second, improve practical learning ability of college students with competition in place of practice. There are more and more various e-commerce competitions in China, including national e-commerce innovation and entrepreneurship challenge match for college students sponsored by the Ministry of Education, national network business innovation competition sponsored by Internet Society of China and various competitions organized by provinces, cities, districts, schools or enterprises. Administrators of e-commerce major in colleges and universities can improve the students' ability of e-commerce major by allowing them to attend such competition activities or through real cases of enterprises or evaluation index. Through competition in place of training, students can not only improve their practical ability of e-commerce, but also improve their abilities of teamwork, organization and planning and innovative thinking and then improve other comprehensive quality. Third, establish practical training base of e-commerce major so as to provide corresponding practical training opportunities for learners. To cultivate high-quality talents of e-commerce major, strong support of enterprises is required besides elaborate education of colleges and universities. Only through close cooperation between schools and enterprises can the important task of e-commerce talent training be completed better. The ideal scene for connecting theory and practice is e-commerce enterprises. Considering the rapid development of e-commerce in China and large gap of talents of e-commerce major, most e-commerce enterprises expect to resolve the deficiency in talent demand through school-enterprise cooperation and then establish off-campus training base for long-term practical training of college students majoring in e-commerce in order to meet talent demands of e-commerce enterprises. This can not only provide the opportunity of practical training for college students, but also increase the opportunity of employment.

\section{Conclusion}

In conclusion, a huge shortage of professional e-commerce talents will be caused definitely considering the rapid development of e-commerce in China in recent years. How to cultivate comprehensive professional e-commerce talents adapted to actual demands of employers and market development, proficient in modern network technology and familiar with business trade according to current practical situation of China is an issue that must be fully emphasized by various institutions of higher learning in e-commerce talent training. To realize objectives of e-commerce talent training above, various colleges and universities shall adjust their teaching plan timely and flexibly, constantly enhance the construction of teacher group and pay attention to practical teaching of e-commerce so as to cultivate more better professional e-commerce talents with higher quality and lay a good talent foundation for healthy development of Chinese e-commerce industry.

\section{References}

[1] Liu Chunming, Meng Lingxi. Reform and Innovation of Talent Training Mode of E-commerce Major in Independent Colleges - Take College of Humanity Information, Changchun University of Technology for Example. Value Engineering, 2012 (13).

[2] Xing Zhiliang, Wen Xibo, Zhang Ce. Study on Undergraduate E-commerce Talent Training Mode of Applied Universities. Education and Vocation, 2013 (27).

[3] Liu Haiyan, Zhuo Lijie. Discussions on New Training Mode of Professional E-commerce Talents. Economic Research Guide, 2014 (1).

[4] Guo Xiangguo. Analysis on Talent Training Mode of E-commerce Major in Colleges and Universities. Economic Horizon, 2014 (3). 
[5] Xia Qingsong, Ru Zibao. Study on Innovation of Talent Training Mode of E-commerce Major in Higher Vocational Colleges. E-commerce, 2014 (9).

[6] Wu Qinglie. Misunderstanding of E-commerce Talent Training and Professional Development Ideas. China University Training, 2015 (2).

[7] Qiu Bizhen. Analysis on Talent Training Mode of Applied Undergraduate E-commerce Major. E-commerce, 2015 (3). 